\title{
SPILLOVERS AND CONNECTEDNESS OF ECONOMIC POLICY UNCERTAINTY AND EXCHANGE RATE VOLATILITY: EVIDENCE FROM ADVANCED ECONOMIES AND NIGERIA
}

\author{
Aworinde, Olalekan B. ${ }^{2}$, Adetokunbo, Abiodun M. ${ }^{1}$ and Oyedele, Oviku ${ }^{1}$ \\ ${ }^{1}$ Department of Economics, Babcock University, Ilishan-Remo, Nigeria \\ ${ }^{2}$ Department of Economics, Pan Atlantic University, Ibeju-Lekki, Nigeria
}

DOI: 10.46609/IJSSER.2021.v06i04.003 URL: https://doi.org/10.46609/IJSSER.2021.v06i04.003

\begin{abstract}
This study examine spillovers and connectedness among economic policy uncertainty of some advanced economies, Nigeria's interest rate, inflation rate and exchange rate volatility using time-varying parameter vector auto regression (TVP-VAR). The study finds that Nigeria's exchange rate volatility is a net receiver of shocks from economic policy uncertainty of advanced economies. Among the economic policy uncertainty, Japan economic policy uncertainty shocks has higher influence on the volatility of exchange rate in Nigeria. There is presence of bidirectional spillover between economic policy uncertainties of US and Europe. There is greater connectedness between economic policy uncertainty of advanced economies and Nigeria's exchange rate volatility as against when there is inclusion of Nigeria's inflation rate and interest rate. The implication from this study is that policy induced uncertainty from the advanced economies is a significant exogenous factor in the fluctuations of Nigeria's exchange rate. Therefore, policy makers needs to understand what policy actions and inactions of advanced economies that is needed to manage exchange rate fluctuations.
\end{abstract}

Keywords: Exchange rate, Volatility; Economic Policy Uncertainty; Spillovers

JEL Codes: D51; F15; F41

\section{Introduction}

The exchange rate market is well-known to be one of the largest financial and the most liquid markets (Record, 2003). Evidently, governments and market analysts are in search of ways to stabilize this market in order to build and maintain a robust economy. On the other hand, exchange rates exhibiting high volatilities play germane role in causing higher level of uncertainty in consumption in the future (see Devereux, 2004), increasing the level of risks attached to domestic and foreign direct investments (see Byrne \& Davis, 2005; Servén, 2003; Urata\& Kawai, 2000), increasing the volatile nature of business profitability (see Aghion, 


\section{International Journal of Social Science and Economic Research}

ISSN: $2455-8834$

Volume:06, Issue:04 "April 2021"

Bacchetta\&Rancière, 2006; Braun \&Larrain, 2005), increasing interest rates and causing inflation uncertainty alongside reduction in consumption and investments (see Grier \& Grier, 2006), higher international transaction risks and changes in production costs (see Baum \&Caglayan, 2006). All these problems, among others, that associate with exchange rate volatility have increased the array of studies on what can predict exchange rate and its volatility.

The naira-dollar exchange rate was relatively stable from January to October 2014, followed by a period of severe market pressures and volatility (UNECA, 2017). Central Bank of Nigeria (CBN hereafter) countered with several reforms. On 25 November 2014, it adjusted the mid-point of the official exchange rate band by 200 basis points from 3 percent to 5 percent. In February 2015, it closed the official foreign currency auction window and channelled transactions to the interbank market, effectively devaluing the official rate to the interbank rateby about 18 per cent (UNECA, 2017). CBN further tightly managed the interbank exchange rate and introduced restrictions on access to foreign currency, which resulted in a wide spread between the rates on the interbank and bureau de change (BDC hereafter) markets. The annualized naira-dollar average exchange rate depreciated marginally by 0.8 percent, from 157.3 in 2013 to 158.6 in 2014. It further depreciated by 24.9 percent to 196.5 in 2015 (UNECA, 2017). In June 2016, $\mathrm{CBN}$ introduced a flexible exchange rate policy, leaving the exchange rate of the naira to market forces.

A total of US\$10.85 billion and US\$9.98 billion of foreign exchange was sold by the CBN to authorised dealers in the first quarter of 2018 (this was 113.5 percent and 393.0 percent rise above the levels in the fourth quarter of 2017 and the first quarter of 2017 respectively) and fourth quarter of 2019 respectively (CBN, 2018a; 2019). In the first quarter of 2018, BDC sales, inter-bank sales and swap transactions were US $\$ 2.54$ billion (23.4 per cent), US\$1.66 billion (15.3 per cent) and US\$0.44 billion (4.1 per cent). In the last quarter of 2019, foreign exchange sales to BDCs, Interbank, Swaps, Secondary Market Intervention Sales (SMIS) Intervention and Wholesale Forward Intervention fell by 11.2 per cent, 10.1 per cent, 8.0 per cent, 3.5 per cent and 2.3 per cent to US\$0.40billion, US\$1.65 billion, US\$1.24 billion, US\$0.31 and US\$3.34 billion, respectively (CBN, 2019). The first quarter of 2018 reflected rise in swap transactions, sales to BDCs, inter-bank sales and foreign exchange forwards disbursed at maturity as against the preceding quarter (CBN, 2018a). However, in the fourth quarter of 2019, there was decline in foreign exchange sales to the BDCs, interbank, swaps transactions and wholesale forwards compared to the preceding quarter (CBN, 2019).

The CBN, in conjunction with the Banker's Committee, abolished commission on retail foreign exchange transactions in the first quarter of 2018 and sustained its interventions at both the interbank and BDC segments of the foreign exchange market in the first quarter of 2018 and last quarter of 2019. The average exchange rate of the naira to the US dollar at the inter-bank 


\section{International Journal of Social Science and Economic Research}

ISSN: $2455-8834$

Volume:06, Issue:04 "April 2021"

segment appreciated by 0.04 percent to $\$ 305.81 / \mathrm{US} \$$, relative to the level in the last quarter of 2017. The average exchange rate of the naira to the US dollar at the Inter-bank segment, was $\$ 306.95 /$ US\$, which was a depreciation of 0.01 percent in the third quarter of 2019.

At the BDC, the average exchange rate was $\$ 362.63 / \mathrm{US} \$$, which was 0.1 percent appreciation relative to the levels in the last quarter of 2017. At the investors and exporters window, the average exchange rate appreciated by 0.03 percent to $\$ 360.38 /$ US $\$$ in the first quarter of 2018 (CBN, 2018b).In the last quarter of 2019, the average exchange rate for the BDC segment depreciated by 0.08 percent relative to the level in the preceding quarter to $\$ 359.42 / \mathrm{US} \$$, but appreciated by 0.8 percent relative to the corresponding period of 2018. At the "Investors" and "Exporters" (I\&E) window, the average exchange rate depreciated by 0.2 percent to $\$ 362.83$ /US $\$$ relative to the level in the preceding quarter, but appreciated by 0.4 percent, compared with the level in the corresponding period of 2018.

Against this background, it is evident that Nigeria's exchange rate has been experiencing continuous fluctuations over the years and this fluctuations have implications for policies and economic agent's behaviour. Exogenous factors have been advanced as part of the explanations for these fluctuations (Bush \&Noria, 2019) in addition with domestic economic variables (Krol, 2014; Nilavongse, Rubaszek and Uddin, 2020). Policy induced uncertainty has also shown comovement with exchange rate volatility (Krol, 2014; Bartsch, 2019; Chen, Du and Tan, 2019). These studies examined impact of economic policy uncertainty on exchange rate volatility, spillovers of the variables were not examined. Studies (Zhu and Yan, 2015; Huynh, Nasir and Nguyen, 2020) that examined spillovers between economic policy uncertainty and exchange rate volatility were unable to examine spillovers of economic policy uncertainties of Europe, US, Canada and Japan with Nigeria's exchange rate volatility.

The objective of the study is to examine spillovers and connectedness among economic policy uncertainty of Europe, US, Canada and Japan, Nigeria's interest rate, inflation rateand exchange rate volatility. Nigeria is a small open economy that still depends on these advanced economies for her trade and investment decisions and at the same time uses policy actions and inactions of these economies to form directions of behaviour towards economic fundamentals. These observed advanced economies on the other hand form a significant proportion of the world output and trade. This study employed time-varying parameter vector auto-regression (TVPVAR) of Antonakakis and Gabauer (2017) that allows variances to vary through a stochastic volatility Kalman Filter estimation with forgetting factors introduced by Koop and Korobilis (2014). The TVP-VAR overcomes the burden of arbitrary rolling window size and loss of observations. 


\section{International Journal of Social Science and Economic Research}

ISSN: $2455-8834$

Volume:06, Issue:04 "April 2021"

The remaining part of the paper are as follows. Section two and three includes literature review and methodology respectively, while section four and five includes empirical results and conclusion and policy implication respectively.

\section{Literature Review}

Empirical literature has connected exchange rate volatilities with uncertainty in economic policy. To start with, some studies reveal that there is hysteric or contemporaneous relation between economic policy uncertainty and exchange rate volatility. In this case, Balcilar, Gupta, Kyei and Wohar (2016) utilize the Granger causality and non-parametric causality-in-quantiles approach to test whether EPU predicts exchange rate in 16 countries. The result of the linear causality test unravels the inability of EPU to predict exchange rate in all the countries except Brazil, while the non-parametric causality-in-quantiles test reveals that EPU differentials have a predictive power for both exchange rate returns and its variance over the entire conditional distribution for four out of sixteen countries. Nonlinear causality was tested but the study did not test for spillovers between economic policy uncertainty and exchange rate. In the process of employing the dynamic conditional correlation GARCH (DCC-GARCH), Kido (2016) reveals that correlations between US economic policy uncertainty and Japanese yen returns is consistently positive, while that of US economic policy uncertainty and high-yielding currencies returns are consistently negative. Empirical evidence for causality was not provided. Mueller, Tahbaz-Salehi, and Vedolin (2017) suggest that monetary policy uncertainty have an impact on exchange rates and financial trading markets. The study did not test for spillovers of the observed variables. Beckmann and Czudaj (2017) analysed the impact of policy uncertainty on exchange rate expectation and forecast errors. The study also test for direction of causation between policy uncertainty and exchange rate expectation and significant impact of policy uncertainty on forecast errors. The impact of policy uncertainty is less significant for expectation compared to forecast errors.

The work of Colombo (2013), among others, credits the importance of the US economic policy uncertainty. The study favours the use of the structural vector autoregressive (SVAR) model to investigate into the effect of US economic policy uncertainty on the nominal Euro-Dollar exchange rate. The result shows that the influence exerted on the European currency by the US uncertainty shock aggregates to be quantitatively larger than the one exerted by a Euro areaspecific uncertainty shock. Though transmission of structural shock from the US to Euro area was tested, spillovers and causality were not accounted for. For China economic policy uncertainty, Sin (2015) utilize the SVAR to analyze the impact of Chinese uncertainty on the economies of Taiwan and Hong Kong. The findings reveal that uncertainty shocks from the Chinese economy have a significant effect on the exchange rate of Hong Kong and Taiwan. The study focused on impact of Chinese economy on Taiwan and Hong Kong and not the spillovers between the 


\section{International Journal of Social Science and Economic Research}

ISSN: $2455-8834$

Volume:06, Issue:04 "April 2021"

economies. In the same vein, Dai,Zhang, Yuand Li, (2017) adopt the causality-in-quantiles methodology of Chuang et al. (2009) to analyze for the possibility of causality between economic policy uncertainty and exchange rate in China. While considering quantile differences, their study unravels that causality is more significant in the tail quantile interval. Justifying their findings, they note that following the extremely high EPU in 2016, China's exchange rate also experienced high fluctuations during this period. Causality was tested, ignoring the spillovers between economic policy uncertainty and exchange rate.

Another strand of the literature on this nexus notes that the magnitude of the impacts of economic policy uncertainty on exchange rate volatility can vary across countries. In this case, Krol (2014) enquires into the impact of the general economic and economic policy uncertainty on the exchange rate volatility of ten industrial and emerging economies since 1990. The study unveils that exchange rate volatility of some of the currencies examined are directly increased by the domestic and US economic policy uncertainty. The study examined impact of economic policy uncertainty on exchange rate volatility. Spillovers of the variables were not examined. Subsequently, Bartsch (2019) utilize a GARCH model to analyze the nexus between economic policy uncertainty and dollar-pound exchange rate return volatility. Of importance, the study finds that UK, rather than US economic policy uncertainty, contributes to daily dollar-pound exchange rate volatility. Spillovers of the variables were not examined. While using the quantile regression, Chen et al, (2019) explore the asymmetric correlations between exchange rate volatility in China and economic policy uncertainty for China, Hong Kong, US, Europe and Japan. Their findings reveal that China economic policy uncertainty significantly and positively impacts its exchange rate volatility at all quantiles. Furthermore, they reveal that US, Europe and Japan economic policy uncertainty have significant impacts, while Hong Kong economic policy uncertainty insignificantly correlate with China exchange rate volatility. The study examined heterogeneous impact of economic policy uncertainty on exchange rate volatility, however, spillovers of the variables were not examined.

With the use of similar quantile predictive regression, the study of Christou, Gupta, Hassapis and Suleman, (2018) seem to be more concerned about the role of economic policy uncertainty in predicting exchange rate returns and its volatility. While employing US dollar based exchange rate of thirteen countries, and the U.S and domestic economic policy uncertainty of these countries, the study shows that economic policy uncertainty demonstrates superior predictive power at low and high order quantiles in all countries except South Africa. EPU forecast ability in predicting exchange rate was examined with no interest on spillovers and causality. Bush and Noria (2019) examined the effect of domestic and global uncertainty on Mexico exchange rate. The study finds that domestic uncertainty and global EPU are major determinants of exchange rate volatility. Nilavongse et al, (2020) examined the UK economy's reaction to uncertainty 


\section{International Journal of Social Science and Economic Research}

ISSN: $2455-8834$

Volume:06, Issue:04 "April 2021"

shocks from UK and US. The study finds that local uncertainty shocks strongly affect the value of British pound.

Few studies have addressed the pass-through of economic policy uncertainty to exchange rate movements from other uncommon approaches such as using panel analysis and examining dynamic spillovers. For instance, different panel estimation techniques are employed by the recent study of Olanipekun, Olasehinde-Williams and Güngör (2019) to examine the impact of economic policy uncertainty on exchange market pressure in 20 countries between 2003Q1 and 2017Q4. Evidence of long run relationship between economic policy uncertainty and exchange rate pressure is established. Additionally, they disclose that the choice of country to choose between the fixed, flexible and intermediate exchange rate regime does not change the significant influence of economic policy uncertainty on the foreign exchange market. Economic policy uncertainty impact was examined and with no focus on spillovers and causality. In another dimension, Zhu and Yan (2015) focus on the dynamic spillovers of economic policy uncertainties and China currency with findings supporting the significant spillover effect of economic policy uncertainties of China, Euro area, Japan and US to Chinese currency. Spillovers between series of EPU and exchange rate was examined but causality was not examined. Zhou, $\mathrm{Fu}$, Jiang, Zeng, and Lin (2020) investigates the impact of Sino-US economic policy uncertainty ratio on the Chinese exchange rate volatility by employing GARCH-MIDAS model. The study shows that the Sino-US EPU ratio has a positive impact on the long term volatility of the Chinese exchange rate. Impact of the Sino-US EPU ratio on exchange rate volatility was examined. Spillovers of the series were not considered.

Al-Yahyaee, Shahzad and Mensi (2020) examines dependence structure and nonlinearity between economic policy uncertainty and major real foreign exchange markets using quantileon-quantile approach. The results show asymmetric dependence structure across the quantiles. There is a weak and strong evidence of causality-in-mean and causality-in-variance respectively and finds that there is intensified linkages during the 2008-2009 global financial crisis. The study examines that the U.S. EPU impact on exchange rates varies across quantiles but does not examine the spillovers of the EPU and the exchange rates. Abid (2020) examines the role of economic policy uncertainty in explaining exchange rate movements in emerging markets. The study employs autoregressive distributed lag (ARDL) model and finds that economic policy uncertainty improves the forecasting power of macroeconomic models of exchange rate in the short-run and long-run. Impact of EPU was the concern of the study however, spillovers were not examined. Chen, $\mathrm{Du}$ and $\mathrm{Hu}$ (2020) investigates relationship between exchange rate volatility in China and EPU of different markets using quantile regression. The study finds an asymmetric impact of EPU on exchange rate volatility in China. EPU of various market has heterogeneous effect on exchange rate volatility. Huynh et al, (2020) analysed the spillover and connectedness 
of exchange rates and trade policy uncertainty. The study observed asymmetric spillovers and connectedness among the exchange rates when trade policy uncertainty is present. Diebold and Yilmaz $(2012$; 2014) was used to examine spillovers, hence time-varying features that TVPVAR could examined might not have been accounted for.

\subsection{Methodology}

\subsection{Theoretical Framework and Model Specification}

Obstfeld and Rogoff (1996) assume that the government's loss function takes the form:

$$
L=\frac{1}{2} E\left[\alpha(y-\hat{y})^{2}+\pi^{2}\right]
$$

Where $y$ is $(\log )$ real GDP, $\hat{y}$ is the government's target for $y, \pi$ is the inflation rate, $E$ captures mathematical expectation, and $\alpha$ is the positive parameter which captures the importance of the output target relative to inflation, which is assumed to have a target of zero.

Output is given by an expectations-augmented Phillips curve;

$$
y=\beta\left(\pi-\pi^{e}\right)+u
$$

Interpreting $y$ as deviations from trend component of output, the natural rate of output has been normalized to zero. $\pi^{e}$ is expected inflation, $u \sim i i d\left(0, \sigma_{u}^{2}\right)$ is an output shock, and $\beta$, which is the slope of aggregate supply is a parameter that captures the Phillips curve trade-off between inflation and output.

Considering two implications of openness and firstly making $\beta$ a decreasing function of openness in order to incorporate the assumption that output-inflation Phillips curve trade-off is worse in an open economy than in a closed economy (Obstfeld and Rogoff, 1996). Thus, we assume:

$$
\beta=\beta \text { (open) }
$$

with $\beta^{\prime} \equiv \frac{\delta \beta}{\delta \text { open }}<0$, where the variable open measures the degree of openness of the economy. Secondly and following Obstfeld and Rogoff (1996), purchasing power parity (PPP) relationship is included:

$$
\pi=\Delta e+v=\varepsilon+v
$$

where $\mathrm{e}$ is the (log, nominal) exchange rate. $\varepsilon \equiv \Delta$ eis the (nominal) depreciation rate, the error term $v \sim i i d\left(0, \sigma_{v}^{2}\right)$ captures deviations from exact PPP, and the foreign price level is assumed to be exogenous and has been normalized to 1 . 
The policy goal is to select $\varepsilon$ in order to minimize (3.1) subject to (3.2), (3.3) and (3.4). The assumption is that policymakers solve for $\varepsilon$ after they observe $u$ but before they observe $v$. The public forms inflation expectations before they observe either $u$ or $v$.

The first-order condition implies that the optimum depreciation rate must satisfy;

$$
\varepsilon^{D}=\frac{\alpha \beta^{2} \varepsilon^{e}-\alpha \beta u+\alpha \beta \hat{y}}{\alpha \beta^{2}+1}
$$

$\varepsilon^{D}$ is expected depreciation. Drepresents discretion. At equilibrium, $\varepsilon^{e}=E\left(e^{D}\right)$, which gives $\varepsilon^{e}=\alpha \beta \hat{y}$, and therefore

$$
\varepsilon^{D}=\alpha \beta \hat{y}-\frac{\alpha \beta}{\alpha \beta^{2}-1} u
$$

Average depreciation rate which according to (3.5) is given by $\bar{\varepsilon}^{D}=\alpha \beta \hat{y}$ can be derived, hence $\frac{d \bar{\varepsilon}^{D}}{\text { dopen }}<0$. The model predicts that more open economies will have a lower average depreciation rate. Following Karras (2006), exchange rate volatility would then be,

$\sigma_{E}=\chi+\varphi$ open $+\vartheta$ size $+u_{t}(3.6)$

where $\sigma_{E}$ is the exchange rate volatility, $\chi$ is the constant, $\varphi$ and $\vartheta$ are the coefficients of openness and economic size respectively.

Following from (3.6), empirical model of exchange rate volatility takes the form

$$
\sigma_{E_{t}}=\chi_{t}+\operatorname{\varphi open}_{t}+\vartheta X_{t}+u_{t}
$$

where $\sigma_{E_{t}}$ is the exchange rate volatility, $X$ is the vector of other variables in (3.6) such as interest rate, inflation rate that could influence exchange rate volatility. Other parameters are as previously specified. To achieve the purpose of this study, economic policy uncertainty comes into (3.7) through openness. Hence (3.7) becomes

$$
\sigma_{E_{t}}=\chi_{t}+\varphi^{\prime} \sigma_{E_{t-1}}+\varphi E P U_{t}+\vartheta X_{t}+u_{t}
$$

where $\sigma_{E_{t-1}}$ is the lagged values of exchange rate volatility and $\varphi^{\prime}$ is its coefficient. $E P U_{t}$ represents economic policy uncertainty of the advanced economies. Other variables in (3.8) are Nigeria's macroeconomic variables. $\varphi$ is the economic policy uncertainty coefficient.

It is expected that there would be some level of connectedness of Nigeria's exchange rate volatility with economic policy uncertainty and other Nigeria's macroeconomic variables because of the notion of increasing integration of economies. We also expect that exchange rate volatility would be a net receiver of spillovers. 
International Journal of Social Science and Economic Research

ISSN: 2455-8834

Volume:06, Issue:04 "April 2021"

\subsection{Data Description and Sources}

The exchange rate is the monthly average official exchange rate of the Naira to US dollar. The inflation series is the headline consumer price index. The interest rate used is the Nigeria bank lending rate. Economic policy uncertainty of Canada, Japan, US and Europe are used. The volatility series of exchange rate is obtained by employing a $\operatorname{GARCH}(1,1)$ model. The sample period runs from January 1995 to December 2019. Headline consumer price index, lending rate, and official exchange rate of the Naira to US dollar are sourced from Thomson Reuters Data stream and the economic policy uncertainty index are sourced from http://www.policyuncertainty.com.

\subsection{Estimation Technique: Time-Varying Parameter Vector Auto-Regression (TVP-VAR)}

Dynamic spillovers and connectedness of the series are to be examined using time-varying parameter vector auto regression. The study would be using TVP-VAR as proposed by Antonakakis and Gabauer (2017). The model extends the Diebold and Yilmaz (2009, 2012 and 2014) connectedness approach, allowing the variances to vary through a stochastic volatility Kalman Filter estimation with forgetting factors introduced by Koop and Korobilis (2014). The TVP-VAR overcomes the burden of arbitrary rolling window size and loss of observations. The TVP- VAR model is written as follows,

$$
\begin{gathered}
Y_{t}=\beta_{t} Y_{t-1}+\epsilon_{t} \epsilon_{t} \mid F_{t-1} \sim N\left(0, S_{t}\right) \\
\beta_{t}=\beta_{t-1}+v_{t} v_{t} \mid F_{t-1} \sim N\left(0, R_{t}\right)
\end{gathered}
$$

Where $Y_{t}$ represents an $N \times 1$ conditional volatilities vector, $Y_{t-1}$ is an $N_{p} \times 1$ lagged conditional vector, $\beta_{t}$ is an $N \times N_{p}$ dimensional time-varying coefficient matrix and $\epsilon_{t}$ is an $N \times$ 1 dimesional error disturbance vector with an $N \times N$ time varying variance-covariance matrix, $S_{t}$. The parameters $\beta_{t}$ depend on their own values $\beta_{t-1}$ and on an $N \times N_{p}$ dimensional error matrix with an $N_{p} \times N_{p}$ variance-covariance matrix.

The time-varying coefficients and error covariances are used to estimate the generalized connectedness procedure of Diebold and Yilmaz (2014) which is based on generalized impulse response functions (GIRF) and generalized forecast error variance decompositions (GFEVD) developed by Koop, Pesaran and Potter (1996) and Pesaran and Shin (1998). To calculate the GIRF and GFEVD, the VAR is transform to its vector moving average (VMA) based on Wold representation theorem as follows:

$$
\begin{gathered}
Y_{t}=\beta_{t} Y_{t-1}+\epsilon_{t}(3.11) \\
Y_{t}=A_{t} \epsilon_{t}(3.12)
\end{gathered}
$$$$
A_{0, t}=I
$$ 


$$
A_{i}, t=\beta_{1, t} A_{i-1, t}+\cdots+\beta_{p, t} A_{i-p, t}
$$

where $\beta_{t}=\left\lfloor\beta_{1, t}, \beta_{2, t}, \ldots \ldots, \beta_{p, t}\right\rfloor^{\prime}$ and $A_{t}=\left\lfloor A_{1, t}, A_{2, t}, \ldots \ldots, A_{p, t}\right\rfloor^{\prime}$ and hence $\beta_{i, t}$ and $A_{i, t}$ are $N \times$ $N$ dimensional parameter matrices.

The GIRFs represent the responses of all variables following a shock in variable $i$.Then, we consider the differences between variable $i$ is shocked or not at J-step ahead forecast. The difference can be accounted to the shock in variable $i$ and calculated as:

$$
\begin{gathered}
G I R F_{t}\left(J, \delta_{j, t}, F_{t-1}\right)=E\left(Y_{t+J}=\delta_{j, t}, F_{t-1}\right)-E\left(Y_{t+J} \mid F_{t-1}\right) \\
\Psi_{j, t}^{g}(J)=\frac{A_{j, t} S_{t} \epsilon_{j, t}}{\sqrt{S_{j j, t}}} \frac{\delta_{j, t}}{\sqrt{S_{j j, t}}} \delta_{j, t}=\sqrt{S_{j j, t}} \\
\Psi_{j, t}^{g}(J)=S_{j j, t}^{-\frac{1}{2}} A_{J, t} S_{t} \epsilon_{j, t}
\end{gathered}
$$

where $\mathrm{J}$ represents the forecast horizon, $\delta_{j, t}$ the selection vector with one vector on the $j t h$ position and zero otherwise, and $F_{t-1}$ the information set until $t-1$.

The GFEVD is then computed as the variance share one variable has on others. These variance shares are then normalized, so that each row sums up to one. That is, all variables together explain $100 \%$ of variable's forecast error variance. The GFEVD is calculated as follows:

$$
\widetilde{\phi_{l \jmath, t}}(J)=\frac{\sum_{t=1}^{J-1} \Psi_{\mathrm{i}, \mathrm{j}, \mathrm{t}}^{2, g}}{\sum_{j=1}^{N} \sum_{t=1}^{J-1} \Psi_{\mathrm{i}, \mathrm{j}, \mathrm{t}}^{2, g}}
$$

with $\sum_{j=1}^{N} \widetilde{\phi_{l \jmath, t}}(J)=1$ and $\sum_{j=1}^{N} \widetilde{\phi_{l, t}^{N}}(J)=N$. With the GFEVD, total connectedness index which is the interconnectedness of the network.

$$
\begin{aligned}
C_{t}^{g}(J) & =\frac{\sum_{i, j=1, i \neq j}^{N} \widetilde{\phi_{l \jmath, t}}(J)}{\sum_{i, j=1}^{N} \widetilde{\phi_{l \jmath, t}}(J)} \times 100 \\
C_{t}^{g}(J) & =\frac{\sum_{i, j=1, i \neq j}^{N} \widetilde{\phi_{l j, t}^{g}}(J)}{N} \times 100
\end{aligned}
$$

Equation (3.19) measures the contribution of spillovers of the advanced economies policy induced uncertainty and Nigeria macroeconomic volatility to the total forecast error variance.This connectedness approach shows how a shock in one variable spill over to other variables. It is possible to assess quantitatively the direction of spillovers variables. The case where variable $i$ transmits its shock to all other variables $j$ called total directional connectedness to others and defined as 


$$
C_{i \rightarrow j, t}^{g}(J)=\frac{\sum_{j=1, i \neq j}^{N} \widetilde{\phi_{\jmath l, t}^{g}}(J)}{\sum_{j=1}^{N} \widetilde{\phi_{\jmath l, t}^{g}}(J)} \times 100
$$

The directional connectedness variable $i$ receives from variables $j$ is called total directional connectedness from others and defined as

$$
C_{i \leftarrow j, t}^{g}(J)=\frac{\sum_{j=1, i \neq j}^{N} \widetilde{\phi_{l \jmath, t}^{g}}(J)}{\sum_{i=1}^{N} \widetilde{\phi_{l \jmath, t}^{g}}(J)} \times 100
$$

Subtracting 'total directional connectedness to others' from 'total directional connectedness from others', we obtain the net total directional connectedness. This can be interpreted as variable $i$ influence on the whole variables network.

$$
C_{i, t}^{g}=C_{i \rightarrow j, t}^{g}(J)-C_{i \leftarrow j, t}^{g}(J)
$$

If the net total directional connectedness of variable $i$ is positive, this means that variable $i$ influences the network more than being influenced. If the net total directional connectedness is negative, this means that variable $i$ is driven by the network.

We can also breakdown the net total directional connectedness to examine the bidirectional relationships by computing the net pairwise directional connectedness (NPDC),

$$
N P D C_{i j}(J)=\frac{\widetilde{\phi_{l l, t}}(J)-\widetilde{\phi_{l \jmath, t}}(J)}{N} \times 100
$$

\section{Empirical Results}

\subsection{Descriptive Statistics}

On average, we observe positive values for the series except interest rate over the period under review, indicating that policy induced uncertainty, exchange rate volatility and inflation have positive on the average and interest rate shows indication of negative values throughout the study period. In terms of their standard deviation, policy induced uncertainty are more volatile as Canada economic policy uncertainty shows higher volatility. The Jarque-Bera test rejects the null hypothesis of normal distribution for all the series following from the reports of both the skewness and kurtosis statistics. While the skewness values hover between positive and negative for all the series, their kurtosis estimates are larger than the standard threshold, especially exchange rate volatility. This suggests the presence of fluctuations. 
International Journal of Social Science and Economic Research

ISSN: 2455-8834

Volume:06, Issue:04 "April 2021"

Table 4.1: Descriptive Statistics

\begin{tabular}{|c|c|c|c|c|c|c|c|c|}
\hline Variables/Statistic & Mean & Махітит & Міпітит & $\begin{array}{c}\text { Std. } \\
\text { Dev. }\end{array}$ & Skewness & Kurtosis & Jarque-Bera & Obs. \\
\hline USepu & 0.192 & 103.77 & -94.131 & 21.765 & 0.381 & 7.387 & $246.145 * * *$ & 298 \\
\hline Jaepu & 0.089 & 93.373 & -109.567 & 24.082 & -0.326 & 7.065 & $210.477 * * *$ & 298 \\
\hline Еиери & 0.347 & 234.813 & -211.011 & 37.969 & 0.488 & 11.327 & $872.835^{* * *}$ & 298 \\
\hline Саери & 0.636 & 198.791 & -146.083 & 50.193 & 0.551 & 5.552 & $95.977 * * *$ & 298 \\
\hline$\sigma_{E}$ & 0.757 & 16.577 & 0.533 & 1.307 & 9.999 & 108.745 & $143808.900 * * *$ & 298 \\
\hline$\pi$ & 0.982 & 5.3 & -1.9 & 1.146 & 0.639 & 4.069 & $34.464 * * *$ & 298 \\
\hline$i$ & -0.018 & 3.31 & -4.05 & 0.58 & -0.709 & 16.85 & $2406.890 * * *$ & 298 \\
\hline
\end{tabular}

Source: Author's computation, 2021

USepu: US economic policy uncertainty

Jaepu: Japan economic policy uncertainty

Euepu: Europe economic policy uncertainty

Caepu: Canada economic policy uncertainty

$\sigma_{E}$ :exchange rate volatility

$i$ :interest rate

$\pi$ : inflation rate.

\section{4..2 Stationarity Tests}

We account for the stationarity properties of the series. We utilize the NG-Perron, Dickey fuller GLS, Phillip Perron, Augumented Dickey fuller (ADF) and Kwiatkowski-Phillips-SchmidtShin (KPSS) (Table 4.2). As grounded by these tests, all the variables are stationary.

Table 4.2: Unit Root Tests

\begin{tabular}{|c|c|c|c|c|c|}
\hline Variables\Tests & $\begin{array}{l}\text { Dickey } \\
\text { Fuller GLS }\end{array}$ & Ng Perron & $A D F$ & $P P$ & KPSS \\
\hline USepu & $13.485^{* * *}$ & $0.029 * * *$ & $-13.542 * * *$ & $-30.469 * * *$ & $0.042 * * *$ \\
\hline Jаepu & -1.941 & $-1.157 * * *$ & $-14.372 * * *$ & $-36.218 * * *$ & $0.075 * * *$ \\
\hline Еиери & $-13.481 * * *$ & $0.029 * * *$ & $-15.779 * * *$ & $-30.656 * * *$ & $0.027 * * *$ \\
\hline
\end{tabular}


International Journal of Social Science and Economic Research

ISSN: 2455-8834

Volume:06, Issue:04 "April 2021"

\begin{tabular}{c|lllll} 
Caepu & $-3.131 *$ & $-6.945 * * *$ & $-13.332 * * *$ & $-34.768 * * *$ & $0.095 * * *$ \\
$\sigma_{E}$ & $-11.210 * * *$ & $0.052 * * *$ & $-11.183 * * *$ & $-10.169 * * *$ & $0.040 * * *$ \\
$\pi$ & 0.001 & $-0.306 * * *$ & $-11.078 * * *$ & $-11.194 * * *$ & 1.653 \\
$i$ & $-18.975 * * *$ & $0.058 * * *$ & $-19.367 * * *$ & $-19.345 * * *$ & $0.046 * * *$
\end{tabular}

$* * * 1 \%, * * 5 \%, * 10 \%$ significance. All series are stationary at first difference.

Source: Author's computation, 2021

USepu: US economic policy uncertainty

Jaepu: Japan economic policy uncertainty

Euepu: Europe economic policy uncertainty

Caepu: Canada economic policy uncertainty,

$\sigma_{E}$ :exchange rate volatility

$i$ :interest rate

$\pi$ : inflation rate.

\subsection{Dynamic Spillovers and Connectedness Results}

We present two spillovers and connectedness results. Exchange rate volatility and Economic policy uncertainty spillovers and connectedness was examined in one, while exchange rate volatility, economic policy uncertainty, inflation rate and interest rate was examined in the other.

Table 4.3: Exchange Rate Volatility and Economic Policy Uncertainty

\begin{tabular}{|c|c|c|c|c|c|c|}
\hline To & $\sigma_{E}$ & Саери & Еиери & Јаери & USepu & From \\
\hline$\sigma_{E}$ & 91 & 1.3 & 2.7 & 3.8 & 1.2 & 9 \\
\hline Саери & 0.3 & 68.9 & 12.7 & 5.3 & 12.8 & 31.1 \\
\hline Еиери & 1.3 & 11.1 & 64 & 6.2 & 17.4 & 36 \\
\hline Jаери & 1.3 & 6.3 & 7.7 & 77 & 7.7 & 23 \\
\hline Usepu & 0.2 & 12.1 & 17.3 & 6.2 & 64.1 & 35.9 \\
\hline Contribution to others & 3.1 & 30.7 & 40.5 & 21.5 & 39.1 & 135 \\
\hline Net directional connectedness & -5.9 & -0.4 & 4.5 & -1.5 & 3.2 & TCI \\
\hline NPDC transmitter & 4 & 2 & 1 & 3 & 0 & 27 \\
\hline
\end{tabular}

Source: Author's computation, 2021 


\section{International Journal of Social Science and Economic Research}

ISSN: $2455-8834$

Volume:06, Issue:04 "April 2021"

$\sigma_{E}$ : exchange rate volatility; Caepu

Canada economic policy uncertainty

Euepu: Europe economic policy uncertainty

USepu: US economic policy uncertainty

From: the total contribution of shocks from other variables to a variable; To: the total contribution of shocks of a variable to other variables.

In table 4.3, spillovers were observed between exchange rate volatility and EPU of advanced economies. We observe that exchange rate volatility is a net pairwise receiver from EPU with 5.9 percent forecast error variance. Surprisingly, EPUs of Canada and Japan are also net pairwise receiver with -0.4 and -1.4 percent forecast error variance. Canada EPU explains 1.3 percent, 11.1 percent, 6.3 percent and 12.1 percent of the forecast error variance of exchange rate volatility, EPUs of Europe, Japan and US respectively. Europe EPU explains 2.7 percent, 12.7 percent, 7.7 percent and 17.3 percent of the forecast error variance of exchange rate volatility, EPUs of Canada, Japan and US respectively. Japan EPU explains 3.8 percent, 5.3 percent, 6.2 percent and 6.2 percent of the forecast error variance of exchange rate volatility, EPUs of Canada, Europe and US respectively. US EPU explains 1.2 percent, 12.8 percent, 17.4 percent and 7.7 percent of the forecast error variance of exchange rate volatility, EPUs of Canada, Europe, Japan and US respectively.

Going by the 'contribution to others' which is the directional connectedness of Nigeria's exchange rate volatility with advanced economies economic policy uncertainty, it shows that exchange rate volatility transmits 3.1 percent shocks to these economic policy uncertainty. Meanwhile, 'contribution from' which shows the directional connectedness of economic policy uncertainty to Nigeria's exchange rate volatility shows that economic policy uncertainty collectively transmit 9 percent shock to Nigeria's exchange rate volatility. According to the total connectedness index (TCI) the average influence all other variables have on one variable's forecast error variance throughout time is 27 percent. To corroborate the above analyses, the graphical analyses of the spillover from other variables and to other variables, net spillovers and dynamic total connectedness are presented in figure 1 . 

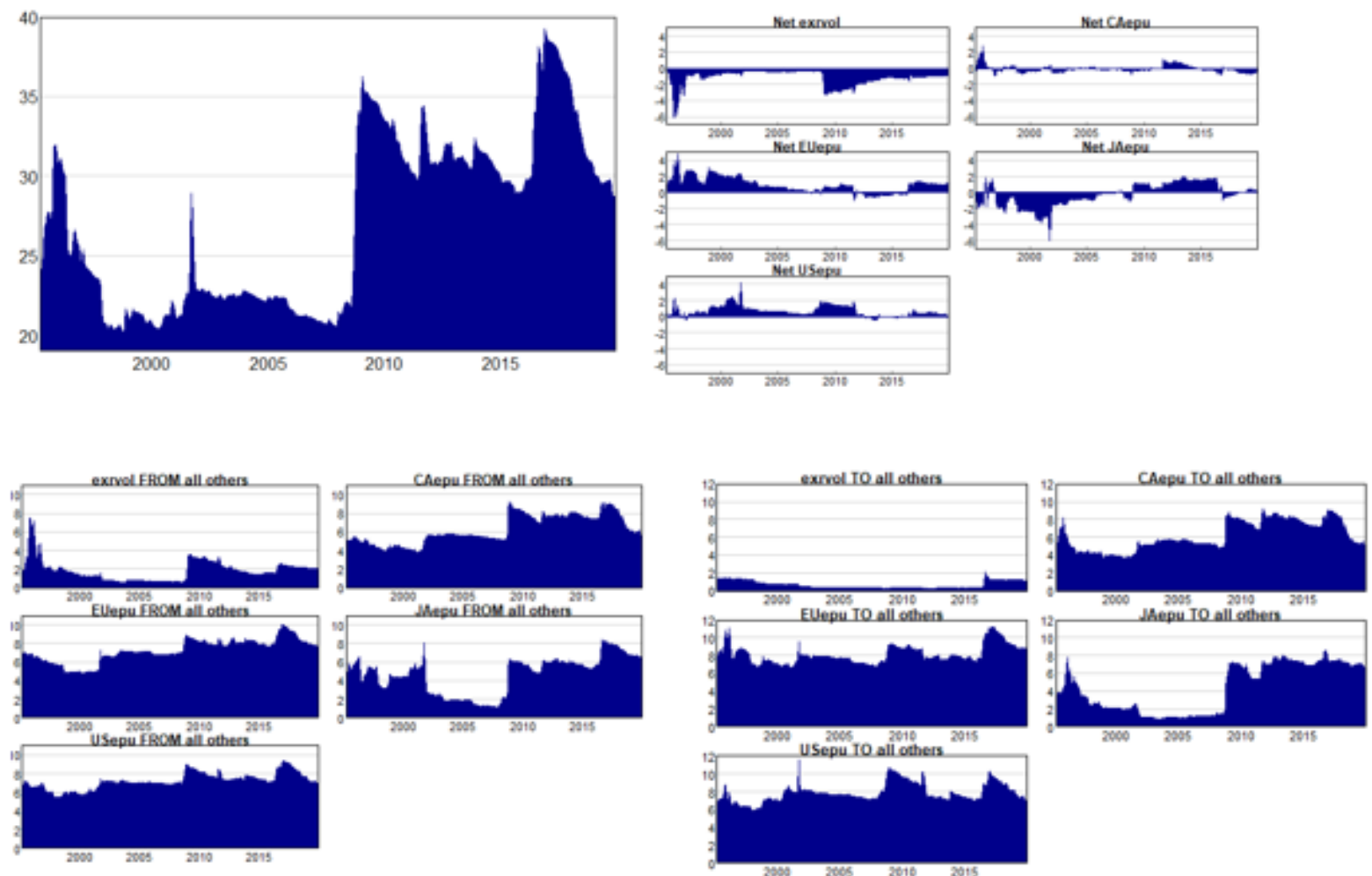

Figure 1: Graphical representation of spillovers and connectedness of exchange rate volatility and Economic policy uncertainty

Table 4.4: Exchange rate volatility, Economic Policy Uncertainty and other Macroeconomic Variables

\begin{tabular}{|c|c|c|c|c|c|c|c|c|}
\hline To & $\sigma_{E}$ & Саери & Еиери & Јаери & USери & $\pi$ & $i$ & From \\
\hline$\sigma_{E}$ & 89.3 & 1.2 & 2.5 & 3.7 & 1.2 & 1 & 1.2 & 10.7 \\
\hline Саери & 0.3 & 68.3 & 12.6 & 5.2 & 12.6 & 0.7 & 0.3 & 31.7 \\
\hline Еиери & 1.2 & 10.9 & 63.6 & 6.1 & 17.3 & 0.4 & 0.4 & 36.4 \\
\hline Jаери & 1.2 & 6.2 & 7.7 & 76.9 & 7.7 & 0.1 & 0.2 & 23.1 \\
\hline USepu & 0.2 & 12 & 17.3 & 6.2 & 64 & 0.2 & 0.2 & 36 \\
\hline$\pi$ & 1 & 3.4 & 2.8 & 2 & 4.8 & 84.4 & 1.5 & 15.6 \\
\hline$i$ & 5.8 & 2.5 & 4.3 & 3.2 & 4.1 & 0.7 & 79.4 & 20.6 \\
\hline Contribution to others & 9.8 & 36.3 & 47.3 & 26.4 & 47.7 & 3.1 & 3.7 & 174.1 \\
\hline $\begin{array}{l}\text { Net directional } \\
\text { connectedness }\end{array}$ & -0.9 & 4.7 & 10.9 & 3.2 & 11.6 & -12.5 & -17 & TCI \\
\hline
\end{tabular}


International Journal of Social Science and Economic Research

ISSN: 2455-8834

Volume:06, Issue:04 "April 2021"

NPDC transmitter $\mid$

2

1

3

0

6

5

24.9

\section{Source: Author's Computation, 2021}

$\sigma_{E}$ : exchange rate volatility

Caepu: Canada economic policy uncertainty

Euepu: Europe economic policy uncertainty

USepu: US economic policy uncertainty

$\pi$ : inflation rate

$i$ : interest rate

From: the total contribution of shocks from other variables to a variable; To: the total contribution of shocks of a variable to other variables.

In Table 4.4, we present the dynamic connectedness table of exchange rate volatility, economic policy uncertainty, inflation rate and interest rate. We observe spillovers from exchange rate volatility to economic policy uncertainty and from economic policy uncertainty to exchange rate volatility appears to be very low. Exchange rate volatility explains 0.3 percent, 1.2 percent, 1.2 percent, 0.2 percent, 1 percent and 5.8 percent of the forecast error variance of EPUs of Canada, Europe, Japan, US, inflation rate and interest rate respectively. Canada EPU explains 1.2 percent, 10.9 percent, 6.2 percent, 12 percent, 3.4 percent and 2.5 percent of the forecast error variance of exchange rate volatility, EPUs of Europe, Japan, US, inflation rate and interest rate respectively. Europe EPU explains 2.5 percent, 12.6 percent, 7.7 percent, 17.3 percent, 2.8 percent and 4.3 percent of the forecast error variance of exchange rate volatility, EPUs of Canada, Japan, US, inflation rate and interest rate respectively. Japan EPU explains 3.7 percent, 2 percent, 3.2 percent, 5.2 percent, 6.1 percent and 6.2 percent of the forecast error variance of exchange rate volatility, inflation rate, interest rate, EPUs of Canada, Europe and US respectively. US EPU explains 1.2 percent, 4.8 percent, 4.1 percent, 12.6 percent, 17.3 percent, and 7.7 percent of the forecast error variance of exchange rate volatility, inflation rate, interest rate, EPUs of Canada, Europe and Japan respectively.

Inflation rate explains 1 percent, 0.7 percent, 0.7 percent, 0.4 percent, 0.1 percent, 0.2 percent of the forecast error variance of exchange rate volatility, interest rate, EPUs of Canada, Europe, Japan and US respectively. Interest rate explains 1.2 percent, 1.5 percent, 0.3 percent, 0.4 percent, 0.2 percent and 0.2 percent of forecast error variance of exchange rate volatility, inflation rate, EPUs of Canada, Europe, Japan, and US respectively. In relations to net spillovers, the EPUs are net transmitter of shocks. US EPU seems to be higher with 11.6 percent, followed 
International Journal of Social Science and Economic Research

ISSN: 2455-8834

Volume:06, Issue:04 "April 2021"

by Europe EPU with 10.9 percent. EPUs of Canada and Japan with 4.7 percent and 3.2 percent respectively. Exchange rate volatility, inflation rate and interest rate are net receiver of shocks, although interest rate appears to be the highest with -17 percent, followed by inflation rate and exchange rate volatility with -12.5 percent and -0.9 percent respectively.

Going by the 'contribution to others' which is the directional connectedness of Nigeria's exchange rate volatility with economic policy uncertainty and Nigeria's macroeconomic variables, it shows that exchange rate volatility transmits 9.8 percent shocks to economic policy uncertainty and Nigeria's macroeconomic variables. Meanwhile, 'contribution from' which shows the directional connectedness of economic policy uncertainty and Nigeria's macroeconomic variables to Nigeria's exchange rate volatility shows that economic policy uncertainty and Nigeria's macroeconomic variables collectively transmit 10.7 percent shock to Nigeria's exchange rate volatility.To corroborate the above analyses, the graphical analyses of the spillover from other variables and to other variables, net spillovers and dynamic total connectedness are presented in figure 2.

From Table 4.3 and Table 4.4, we observe that exchange rate volatility is a net receiver of shocks from economic policy uncertainty. Among the economic policy uncertainty, Japan EPU records the highest contribution to the forecast error variance of exchange rate volatility. Intuitively, Japan EPU shocks would have a higher influence on the volatility of exchange rate in Nigeria. There is presence of bidirectional spillover between EPUs of US and Europe. US EPU contributes the highest to the forecast variance of EU EPU and EU EPU contributes the highest to the forecast variance of US EPU. In terms of the total connectedness index, there is greater connectedness between economic policy uncertainty and exchange rate volatility as against when there is inclusion of inflation rate and interest rate. The implication of this, is that the observed economic policy uncertainty transmits shocks to Nigeria's exchange rate than Nigeria's economic variables. 


\section{International Journal of Social Science and Economic Research}

ISSN: 2455-8834

Volume:06, Issue:04 "April 2021"
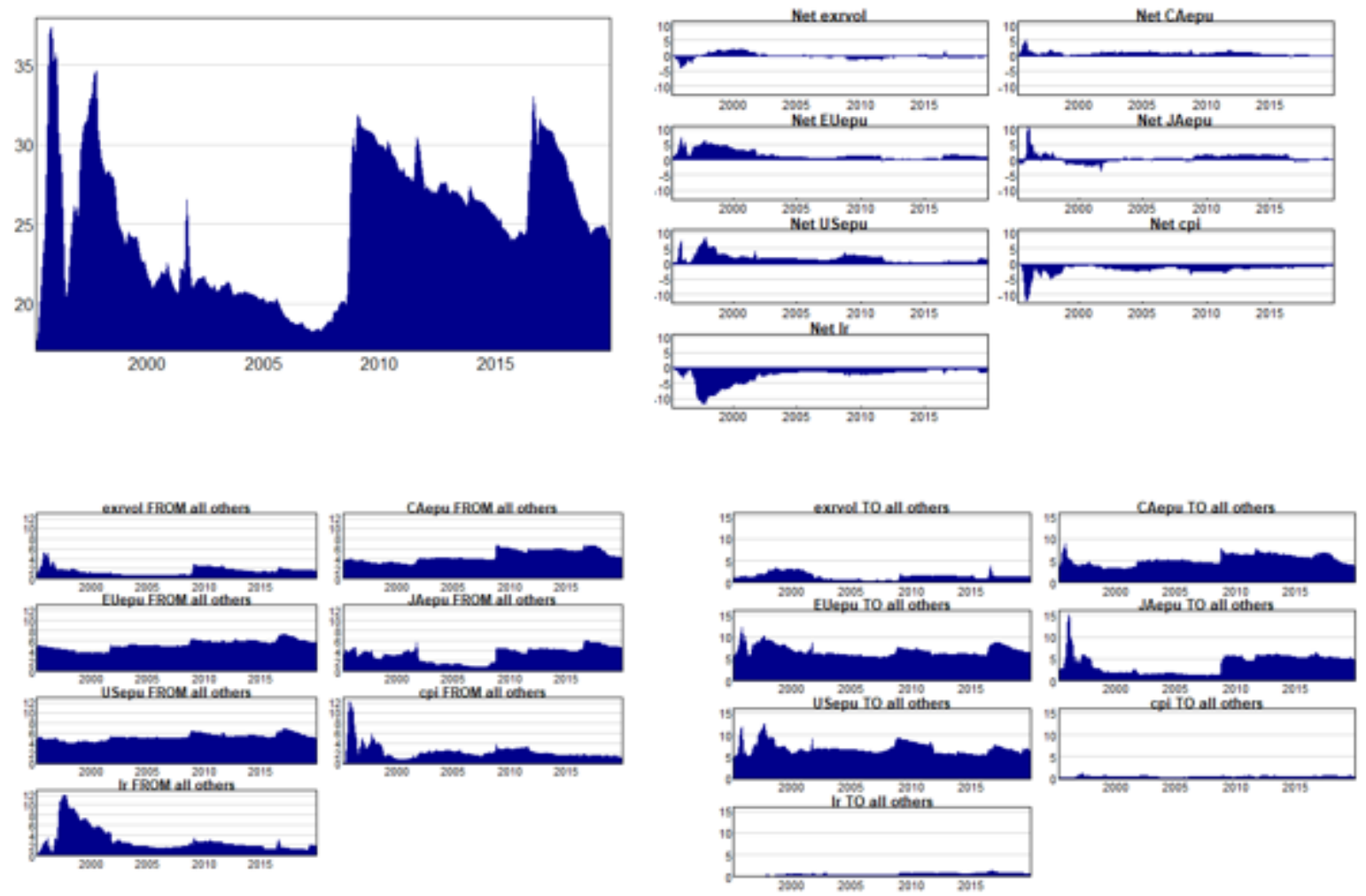

Figure 2: Graphical representation of spillovers and connectedness of exchange rate volatility, Economic policy uncertainty, inflation rate and interest rate

\subsection{Discussion of Findings}

There are spillovers and connectedness among economic policy uncertainty of advanced economies, Nigeria's interest rate, inflation rate and exchange rate volatility. Exchange rate volatility, interest rate and inflation rate are net receivers of spillovers from the economic policy uncertainty. As Krol (2014) and Bush and Noria (2019) reports exchange rate volatility are determined by domestic and global economic policy uncertainty, there are spillovers from economic policy uncertainty and domestic economic variables to exchange rate volatility. The findings also support argument that uncertainty stemming from an economy could have significant effect on the exchange rate of another economy (Sin, 2015), as economic policy uncertainty of advanced economies is observed to have spillover effects on Nigeria's exchange rate volatility. From the findings, economic policy uncertainty contribute to exchange rate volatility, this is tandem with Bartsch (2019). Zhu and Yan (2015) observes that net spillover comes from the economic policy uncertainty on RMB exchange rate, this study also finds Nigeria's exchange rate volatility to be net receiver of shocks from economic policy uncertainty. 


\section{International Journal of Social Science and Economic Research}

ISSN: $2455-8834$

Volume:06, Issue:04 "April 2021"

Chen et al., (2019) observes that economic policy uncertainty from different economies have heterogeneous impact on an economy's exchange rate volatility, this study also observe that advanced economies economic policy uncertainty have differing spillover effects on Nigeria's exchange rate volatility, particularly Japan economic policy uncertainty has greater spillover effect on Nigeria's exchange rate volatility than other economic policy uncertainty under this empirical investigation. This evidence of greater spillover from Japan economic policy uncertainty might reflect high degree of commodity complementarity (Fajana, 1976) that facilitates trade between these economies. There is also bidirectional spillover between Europe economic policy uncertainty and US economic policy uncertainty. The level and nature of relationship of these economies in transatlantic investments might account for these bidirectional spillovers.

\section{Conclusion}

This study examine spillovers and connectedness among economic policy uncertainty of some advanced economies, Nigeria's interest rate, inflation rate and exchange rate volatility using time-varying parameter vector auto regression (TVP-VAR). The study finds that Nigeria's exchange rate volatility is a net receiver of shocks from economic policy uncertainty of advanced economies. Among the economic policy uncertainty, Japan economic policy uncertainty shocks has higher influence on the volatility of exchange rate in Nigeria. There is presence of bidirectional spillover between economic policy uncertainties of US and Europe. There is greater connectedness between economic policy uncertainty of advanced economies and Nigeria's exchange rate volatility as against when there is inclusion of Nigeria's inflation rate and interest rate. The implication from this study is that policy induced uncertainty from the advanced economies is a significant exogenous factor in the fluctuations of Nigeria's exchange rate. Therefore, policy makers needs to understand what policy actions and inactions of advanced economies that is needed to manage exchange rate fluctuations.

\section{References}

Abid, A. (2020). Economic policy uncertainty and exchange rates in emerging markets: short and long run evidence. Finance Research Letters, 37, 101378.

Aghion, P., Bacchetta, P., \&Rancière, R. (2006). Exchange rate volatility and productivity growth: The role of financial development. Journal of Monetary Economics56, 494-513.

Al-Yahyaee, K. H., Shahzad, S. J. H. \&Mensi, W. (2020). Tail dependence structure between economic policy uncertainty and foreign exchange markets: Nonparametric quantiles methods. International Economics, 161, 66-82. 


\section{International Journal of Social Science and Economic Research}

ISSN: $2455-8834$

Volume:06, Issue:04 "April 2021"

Balcilar, M., Gupta, R.,Kyei, C.\&Wohar, M. A. (2016). Does economic policy uncertainty predict exchange rate returns and volatility? Evidence from a nonparametric causality-inquantiles test. Open Economies Review,27, 229-250.

Bartsch, Z. (2019). Economic policy uncertainty and dollar-pound exchange ratereturn volatility. Journal of International Money and Finance,98, 102067.

Baum, C. F. \&Caglayan, M. (2006). On the sensitivity of the volume and volatilityof bilateral trade flows to exchange rate uncertainty. Journal of International Money \& Finance,29, 79-93.

Beckmann, J. \&Czudaj, R. (2017). Exchange rate expectations and economic policy uncertainty. European Journal of Political Economy, 47, 148-162.

Braun, M. and \&Larrain, B. (2005). Finance and the business cycle: International, interindustryevidence. Journal of Finance, 60, 1097-1128.

Bush, G. \&Noria, G. L. (2019). Uncertainty and Exchange rate volatility: The case of Mexico.Banco de Mexico Working Papers No 2019-12.

Byrne, J. P. \& Davis, E. P. (2005). Investment and uncertainty in G7. Review of World Economics, 141, 1-32.

Central Bank of Nigeria (2018a). Economic Report First Quarter 2018. Central Bank of Nigeria.

Central Bank of Nigeria (2018b). Economic and Financial Review,Central bank of Nigeria.

Central Bank of Nigeria (2019). Economic Report Fourth Quarter 2019. Central Bank of Nigeria.

Chen, L., Du, Z. \& Hu, Z. (2020). Impact of economic policy uncertainty on exchange rate volatility of China. Finance Research Letter, 32.

Chen, L., Du, Z. \& Tan, Y. (2019). Sustainable exchange rates in China: Is there the heterogeneous effectof economic policy uncertainty? Green Finance, 1(4), 346-363.

Christou, C., Gupta, R., Hassapis, C.\&Suleman, T. (2018). The role of economic uncertainty in forecasting exchange rate returns and realized volatility: Evidence from Quantile Predictive Regressions. Journal of Forecasting,37(7), 705-719.

Chuang, C.C., Kuan, C.M. \& Lin, H.Y. (2009). Causality in quantiles and dynamic stock return volume relations. Journal of Banking \& Finance,33(7), 1351-1360.

Colombo, V. (2013). Economic policy uncertainty in the US: Does it matter for the Euro area? Economics Letters, 121, 39-42. 


\section{International Journal of Social Science and Economic Research}

ISSN: $2455-8834$

Volume:06, Issue:04 "April 2021"

Dai, Y., Zhang, J., Yu, X.\& Li, X. (2017). Causality between economic policyuncertainty and exchange rate in China with considering quantile differences.Theoretical and Applied Economics, 24, 29-38.

Devereux, M. B. (2004). Should the exchange rate be a shock absorber? Journal of International Economics, 62(2), 359-377.

Diebold, F. X., \&Yilmaz, K. (2009). Measuring Financial Asset Return and Volatility Spillovers, with Application to Global Equity Markets. The Economic Journal, 119, 158-171.

Diebold, F. X., \&Yilmaz, K. (2012). Better to give than to receive: Predictive directional measurement of volatility spillovers. International Journal of Forecasting, 28(1), 57-66.

Diebold, F. X., \&Yilmaz, K. (2014). On the network topology of variance decompositions: Measuring the connectedness of financial firms. Journal of Econometrics, 182(1), 119134.

Grier, R., \& Grier, K. B. (2006). On the real effects of inflation and inflation uncertainty in Mexico. Journal of Development Economics, 80, 478-500.

Huynh, T. L. D., Nasir, M. A. \& Nguyen, D.K. (2020). Spillovers and connectedness in foreign exchange markets: The role of trade policy uncertainty. The Quarterly Review of Economics and Financehttps://doi.org/10.1016/j.qref.2020.09.001

Karras, G. (2006). Trade openness, economic size and macroeconomic volatility: Theory and Empirical Evidence. Journal of Economic Integration, 21(2), 254-272.

Kido, Y. (2016). On the link between the US economic policy uncertainty and exchange rates. Economic. Letters. 144 (Supplement C), 49-52.

Koop, G. \&Korobilis, D. (2014). A new index of financial conditions. European Economic Review, 71, 101-116.

Koop, G., Pesaran, M. H., \& Potter, S. M. (1996). Impulse response analysis in nonlinear multivariate models. Journal of Econometrics, 74(1), 119-147.

Krol, R. (2014). Economic policy uncertainty and exchange rate volatility. International Finance, 17, 241-256.

Mueller, P., Tahbaz-Salehi, A., \&Vedolin, A. (2017). Exchange rates and monetary policy uncertainty. The Journal of Finance, 72(3), 1213-1252.

Nilavongse, R, Rubaszek, M. \& Uddin, G.S. (2020). Economic policy uncertainty shocks, economic activity and exchange rate adjustments. Economics Letters, 186. 
International Journal of Social Science and Economic Research

ISSN: 2455-8834

Volume:06, Issue:04 "April 2021"

Obstfeld, M. \&Rogoff, K. (1996). Foundations of International Macroeconomics. Cambridge, Massachusetts: MIT Press.

Olanipekun, I. O., Olasehinde-Williams, G. \&Güngör, H. (2019). Impact of economic policy uncertainty on exchange market pressure. SAGE, 113.https://doi.org/10.1177/2158244019876.

Pesaran, H. H. \& Shin, Y. (1998). Generalized impulse response analysis in linear multivariate models. Economics Letters, 58(1), 17-29.

Record, N. (2003). Currency Overlay. The Wiley Finance Series, Wiley, United States.

Servén, L. (2003). Real-exchange-rate uncertainty and private investment in LDCS. Review of Economics and Statistics, 85, 212-218.

Sin, C.Y. (2015). The economic fundamental and economic policy uncertainty of Mainland Chinaand their impacts on Taiwan and Hong Kong. International Review of Economics \& Finance, 40, 298-311.

UNECA (2017). Country Profile 2016: Nigeria. United Nations Economic Commission for Africa.

Urata, S. \& Kawai, H. (2000). The determinants of the location of foreign direct investment by Japanese small and medium-sized enterprises. Small Business Economics, 15, 79-103.

Zhou, Z., Fu, Z., Jiang, Y., Zeng, X. \& Lin, L. (2020).Can economic policy uncertainty predict exchange rate volatility? New evidence from the GARCH-MIDAS model. Finance Research Letters, 34.

Zhu, M.N.\& Yan, S., (2015). Dynamic spillovers of economic policy uncertainty and RMB exchange rate. Journal of International Trade,10, 111. 